$\mathrm{Nr}$ 4(61), 2019, s. 187-205

https://doi.org/10.12797/Politeja.16.2019.61.11

\author{
Monika KOPYTOWSKA (D) \\ Uniwersytet Łódzki \\ mkopytowska@uni.lodz.pl \\ Julita WOŹNIAK iD \\ Uniwersytet Jana Kochanowskiego w Kielcach \\ julitawozniak@op.pl
}

\title{
INTERNET JAKO PRZESTRZEŃ DEBATY NA TEMAT PLURALIZMU KULTUROWEGO
}

\section{PERCEPCJA INTERNETOWEJ MOWY NIENAWIŚCI SKIEROWANEJ DO UCHODŹCÓW/IMIGRANTÓW EKONOMICZNYCH ${ }^{1}$}

ABSTRACT Internet as a Space for Debate on Cultural Pluralism. Perception of Online Hate Speech Targeted at Refugees/Economic Migrants

Being an online space where members of the society can freely and instantaneously exchange their opinions, the Internet has become an ultra-attractive site for extended socio-political debate. At the same time, however, anonymity and global accessibility have transformed it into a tool facilitating the spread of hateful and radical messages, in particular those exploiting religious, ethnic and cultural differences. While multiculturalism and the "Other" have long been the subject of public debate, within this new mediatized public sphere problems and controversies surrounding them have thus acquired a new dimension. What can be observed

W artykule wykorzystane zostały wyniki badań przeprowadzonych w ramach projektu C.O.N.T.A.C.T. (Creating an On-line Network, monitoring Team and phone App to Counter hate crime Tactics JUST/2014/RRAC/AG/HATE/6706), który jest współrealizowany przez uniwersytety i organizacje pozarządowe z dziesięciu krajów Unii Europejskiej, w tym Uniwersytet Łódzki. Celem projektu jest m.in. zbadanie i opisanie językowego procesu tworzenia wizerunku „Innego” w internecie na podstawie analizy mowy nienawiści skierowanej do różnych grup mniejszościowych przebywających w Polsce, a także stworzenie strony internetowej i specjalnej aplikacji mobilnej, za pomocą których możliwe będzie zgłaszanie przypadków mowy nienawiści oraz przestępstw motywowanych nienawiścią (więcej informacji znajduje się na oficjalnej stronie projektu: www.reportinghate.eu). 
is increasing social acceptance of verbal abuse and aggression in online communication, especially when it comes to attacks levelled at various "Others". The article discusses the problem of multiculturalism and otherness in the Polish context, legal definitions used by the EU in their judgments on online hate speech, as well as the perception of hate speech targeted at refugees and immigrants among Polish people (aged 18-35). Some of the findings presented here are based on analyses conducted within the European project C.O.N.T.A.C.T., exploring various aspects of hate speech and hate crime in ten EU countries.

Key words: online hate speech, refugees, economic migrants, cultural pluralism

Słowa kluczowe: internetowa mowa nienawiści, uchodźcy, imigranci ekonomiczni, pluralizm kulturowy

\section{WSTĘP}

Anonimowość cyberprzestrzeni powoduje, że internet staje się forum wymiany radykalnych poglądów (nieskrępowanych normami społecznymi), a język prowadzonej tam debaty publicznej obfituje w określenia negatywne, wulgaryzmy i przesadne metafory. W ostatnich latach celem takich ataków słownych stali się głównie uchodźcy i imigranci ekonomiczni, którzy postrzegani są jako homogeniczna grupa niebezpiecznych „Innych”, stanowiących zagrożenie dla polskiego państwa narodowego ${ }^{2}$. Ze względu na silny ładunek nietolerancji, a nawet rasizmu i ksenofobii, oraz fakt, iż tego typu stwierdzenia deprecjonują osoby odmienne kulturowo i zachęcają do agresji wobec nich, wypowiedzi te noszą znamiona mowy nienawiści. Przedstawione w niniejszym artykule wyniki ankietowego badania percepcji mowy nienawiści pokazują, jak młodzi ludzie rozumieją pojęcie mowy nienawiści i w jakim stopniu wypowiedzi o takim charakterze są (nie)akceptowane. Wypowiedzi respondentów pozwalają także - przynajmniej częściowo - odpowiedzieć na pytanie, dlaczego mowa nienawiści nie spotyka się ze zdecydowanym sprzeciwem społecznym i nadal w zbyt małym stopniu takie przypadki zgłaszane są organom ścigania. Nim przyjrzymy się tym wynikom, warto najpierw - choćby ogólnie - zarysować sytuację pluralizmu kulturowego ${ }^{3}$ w Polsce i podjąć refleksję nad

2 Do takiego stanu rzeczy przyczynił się m.in. trwający od 2015 r. tzw. kryzys migracyjny, postrzegany jako jeden z najpoważniejszych problemów, przed którymi stoją państwa europejskie. Drugą grupą, do której często kierowana jest internetowa mowa nienawiści, są przedstawiciele mniejszości seksualnych, dlatego przykłady takich wypowiedzi również zostały wykorzystane w opisywanym tu badaniu ankietowym.

3 Jak podkreśla A. Giddens, nie należy mieszać pojęć „,wielokulturowość” („multikulturalizm”) i „pluralizm kulturowy”. Wielokulturowość rozumie się jako koncepcję polityczną zakładającą realizację programów, które dostrzegaja autentyczność różnych sposobów życia w ramach spoteczności i dąż do wspierania owocnej i pozytywnej wymiany między nimi, a wszystko to w ramach catościowego, wyjątkowego systemu praw i obowiązów obywatelskich (A. Giddens, Europa w epoce globalnej, przeł. M. Klimowicz, M. Habura, Warszawa 2009, s. 153), podczas gdy pojęciem „pluralizm kulturowy” opisuje się 
tym, jak Polacy postrzegają osoby odmienne kulturowo, które stanowią (lub potencjalnie mogłyby stanowić) integralną część polskiego społeczeństwa.

\section{PLURALIZM KULTUROWY W POLSKIEJ RZECZYWISTOŚCI}

Postrzeganie „Innych” ma po pierwsze - podłoże historyczne, a po drugie - jest zawsze uwarunkowane kulturowo. Trudna historia Polski, naznaczona okresem zaborów i wojen oraz epizodami czystek etnicznych i przymusowych przesiedleń, sprawiła, że w powszechnej świadomości społecznej nie przetrwała tradycja otwartości na odmienność kulturową ${ }^{4}$. W okresie po II wojnie światowej Polska stała się państwem niemal jednolitym pod względem narodowo-etnicznym. Dopiero po 1989 r., kiedy przedstawiciele poszczególnych mniejszości zaczęli otwarcie mówić o swojej kulturowej odmienności i zabiegać o swoje prawa, społeczeństwo polskie zaczęło uświadamiać sobie własną różnorodność kulturową, która w ostatnich latach stopniowo się zwiększa.

Różnorodność kulturowa Polski ma kilka źródeł. Pewne mniejszości narodowe i etniczne wpisały się już na stałe w polski krajobraz społeczno-kulturowy ze względu na fakt, iż często od kilkuset lat zajmują terytorium, które w wyniku różnych historycznych wydarzeń znalazło się we współczesnej Polsce (np. Niemcy i Ormianie, którzy zamieszkują obszar państwa polskiego od średniowiecza, a także Karaimi, Tatarzy czy Romowie). Pojawiły się również nowe grupy mniejszościowe w postaci społeczności imigrantów, którzy przybyli z krajów zarówno bliskich kulturowo (np. Ukraina, Rosja, Armenia), jak i bardziej odległych (np. Wietnam, Chiny czy państwa arabskie i afrykańskie). Ważnym czynnikiem w procesie kształtowania się zróżnicowanej struktury kulturowej społeczeństwa polskiego było także przybycie dość znaczącej liczebnie grupy uchodźców z Czeczeni ${ }^{5}$.Zarówno mniejszości narodowe/etniczne, jak i grupy imigrantów muszą zmierzyć się z problemem asymilacji, która rozumiana jest jako proces stopniowego przyjmowania kultury obcej przy jednoczesnej utracie kultury własnej. Globalizacja i zwiększająca się atrakcyjność kultury masowej powodują, że młode pokolenia grup mniejszościowych coraz rzadziej używają języka ojczystego i nie kultywują własnych obyczajów ${ }^{6} . Z$ drugiej strony wraz z jednoczeniem się państw w obrębie Unii Europejskiej pojawiła się - widoczna także w Polsce - tendencja do podkreślania lokalnej odmienności kulturowej i wielokulturowego charakteru miast czy regionów. Aby wzmacniać ten trend, konieczne wydaje się zapewnienie grupom mniejszościowym odpowiedniego poziomu realizacji ich praw,

społeczeństwo, w którym występują różne grupy kulturowe (por. T. Modood, Multikulturalizm, przeł. I. Kołbon, Poznań 2014).

$4 \quad$ Polska okresu Rzeczpospolitej Obojga Narodów (utworzona na mocy unii lubelskiej w 1569 r.) była ewenementem na skalę europejską pod względem pozytywnego podejścia do różnorodności narodowo-etnicznej i kulturowej oraz polityki tolerancji wobec osób o różnym pochodzeniu kulturowym (por. A. Jawor, Wojna kultur. Czy "flaga tęczowa” wypiera „biato-czerwona”?, Warszawa 2014).

5 Por. M. Ząbek, S. Łodziński, Uchodźcy w Polsce. Próba spojrzenia antropologicznego, Warszawa 2008.

6 A. Giza, M. Głowacka-Grajper, S. Urbańska, Mieszkańcy Polski, [w:] Wspótczesne spoteczeństwo polskie, red. A. Giza, M. Sikorska, Warszawa 2012. 
jak również zastąpienie asymilacji koncepcją integracji ${ }^{7}$, zgodnie z którą osoby o odmiennym pochodzeniu kulturowym mogą wypracować taką formułę funkcjonowania społecznego, aby móc żyć w zgodzie z normami kultury większościowej, nie wyrzekając się przy tym swojej tożsamości etnicznej i nie rezygnując z podtrzymywania więzi etnicznych w obrębie wspólnoty pochodzenia ${ }^{8}$. Co więcej, osoby o odmiennym rodowodzie kulturowym mogą znacząco wpłynąć na jakość funkcjonowania społeczeństwa, wnosząc do niego ciekawe zasoby wiedzy, inne sposoby reagowania na określone sytuacje czy też nowe obrzędy, rytuały i obyczaje (o ile nie kolidują one z normami moralnymi obowiązującymi w państwie przyjmującym) $)^{9}$. Szeroko zakrojona polityka wspierania różnorodności kulturowej społeczeństwa polskiego mogłaby przyczynić się do zwiększenia kapitału kulturowego obywateli i stworzyć ramy instytucjonalne do współpracy ponad podziałami kulturowymi, co w dalszej perspektywie skutkowałoby wzmocnieniem więzi społecznych między grupami o różnej identyfikacji etniczno-narodowej.

Podejmując refleksję na temat pluralizmu kulturowego, z jakim coraz wyraźniej mamy do czynienia w Polsce, warto też zastanowić się nad tym, w jaki sposób osoby odmienne kulturowo są postrzegane przez Polaków identyfikujących się z polską kulturą narodową. Badania socjologiczne wskazują na występowanie w spoteczeństwie polskim postaw nietolerancji rasowej, religijnej i narodowościowej ${ }^{10}$. W Polsce ważniejszym aspektem tożsamości jest narodowość niż obywatelstwo, a w związku z tym - wielu Polaków przejawia trudności w postrzeganiu przedstawicieli mniejszości narodowych/ etnicznych jako współobywateli ${ }^{11}$. Polacy wyrażają też niechęć wobec pewnych grup

$7 \quad$ Integracja jest jednym ze sposobów akulturacji (obok asymilacji, marginalizacji i separatyzmu) (por. C. Tavris, C. Wade, Psychologia. Podejścia oraz koncepcje, przeł. J. Gilewicz, Poznań 1995; J.W. Berry, Acculturation: Living Successfully in Two Cultures, „International Journal of Intercultural Relations” 2005, vol. 29; A. Karwińska, Poziom mezospoteczny, [w:] Odkrywanie socjologii. Podręcznik dla ekonomistów, red. A. Karwińska, Warszawa 2008; A. Kwiatkowska, H. Chodkowska, Identity in a Multicultural Environment: a Gender Perspective, [w:] Culture and Gender in Intimate Relation, red. A. Chybicka, S.F. Safdar, A. Kwiatkowska, Gdańsk 2010).

8 Choć kształtowanie się zintegrowanej tożsamości wielokulturowej jest procesem długim i niełatwym, gdyż oznacza konieczność dokonywania wielu wyborów między elementami obydwu kultur i połączenia ich w spójną całość (wszak przynależność etniczna zapewnia możliwość podstawowej samoidentyfikacji), to jest to proces pożądany, ponieważ - jak podkreślają Tavris i Wade (1999) - osoby rzeczywiście dwukulturowe odczuwają silne więzi zarówno z wtasna grupa etniczną, jak i z kulturą większości (C. Tavris, C. Wade, Psychologia..., s. 381-382).

$9 \quad$ Jak pisze J. Mikułowski Pomorski: Na przyktad $w$ renesansowych miastach wtoskich na stanowiska sędziów powotywano często cudzoziemców jako osoby wolne od stronniczości. Dzięki temu, na zasadzie wykorzystywania tej bezstronności, powstawaty więzi tączące ich z cztonkami tej spoteczności (J. Mikułowski Pomorski, Komunikacja międzykulturowa jako dziedzina nauki. $Z$ historii komunikacji międzykulturowej, [w:] Polifonia, dialog i zderzenie kultur. Antologia tekstów z komunikacji międzykulturowej, red. U. Kusio, Toruń 2007, s. 69).

10 A. Sadowski, Spoteczeństwo polskie - od zróżnicowanego kulturowo do wielokulturowego. Szanse i zagrożenia, [w:] Wielokulturowość: konflikt czy koegzystencja, red. A. Śliz, M.S. Szczepański, Warszawa 2011, s. 70.

11 E. Chromiec, Mniejszości narodowe i etniczne w Polsce - pytania i problemy okresu transformacji, [w:] Spoteczeństwo wobec "Innego". Kategoria „Innego” w naukach spotecznych i życiu publicznym, red. L. Dziewięcka-Bokun, A. Śledzińska-Simon, Toruń 2010. 
imigrantów, takich jak muzułmanie. Badania CBOS dotyczące sympatii/antypatii Polaków wobec reprezentantów różnych narodów ujawniły, że największą antypatię przejawiają oni wobec Arabów, których uważają za prototypowych wyznawców islamu ${ }^{12}$. Należy zaznaczyć, iż w tego typu badaniach grupą jeszcze bardziej nielubianą od Arabów są niekiedy Romowie, którzy także wzbudzają w polskim społeczeństwie odczucia negatywne ze względu na swoją hermetyczność, niezrozumiałą obyczajowość i niechęć do pracy $w$ formie zinstytucjonalizowanej ${ }^{13}$. Wzmożona awersja do pewnych grup kulturowych może być skutkiem tendencji, zgodnie z którą „Inni”, całkowicie odmienni od grupy własnej, postrzegani są jako psychologicznie odlegli i różni pod względem kluczowych wartości i motywów działania ${ }^{14}$. Jak zauważa Justyna Nakonieczna, odnosząc się do negatywnych postaw wobec pewnych grup imigranckich, [...] im większe sq różnice etniczno-kulturowe, tym wyższe prawdopodobieństwo, że poziom percepcji spotecznego zagrożenia zwiąanego z migracjami także będzie róst, co przetoży się na bardziej restrykcyjna politykę migracyjna wobec tych grup migrantów ${ }^{15}$. W pewnym stopniu tłumaczy to fakt, że mowa nienawiści skierowana do uchodźców czy imigrantów ekonomicznych obfituje w pejoratywne określenia muzułmanów ${ }^{16}$.

Debata publiczna na temat masowych migracji ostatnich lat pokazała, że stosunek Polaków do osób odmiennych kulturowo jest bardzo zróżnicowany i waha się od pelnego zrozumienia trudnej sytuacji życiowej, w jakiej znaleźli się uchodźcy, do głębokiej niechęci i uprzedzenia wobec imigrantów, którzy swoją innością mogliby naruszyć polsko-normatywną tożsamość kulturową naszego kraju i obniżyć standard życia Polaków ${ }^{17}$. Za podsumowanie tego rozdziału niech posłużą nam słowa Ireneusza Krzemińskiego, który stwierdza, iż: przypadek Polski zdaje się potwierdzać przekonanie badaczy rasizmu, że wrogie postawy aktywizuja się wtedy, kiedy zachwiane zostaje poczucie

12 A. Stefaniak, M. Witkowska, Spoteczne kontakty Polaków, czyli czy znamy ludzi innych niż my sami i czy chcemy ich poznawać?, [w:] Uprzedzenia w Polsce, red. A. Stefaniak, M. Bilewicz, M. Winiewski, Warszawa 2015.

13 E. Chromiec, Mniejszości...

${ }_{14}$ M. Tarnowska, Kiedy odmawiamy „obcym” części cztowieczeństwa? Uwarunkowania zjawiska infrahumanizacji, [w:] Wobec obcych. Zagrożenia psychologiczne a stosunki międzygrupowe, red. M. Kofta, M. Bilewicz, Warszawa 2011.

15 J. Nakonieczna, Migracje międzynarodowe jako wyzwanie we wspótczesnym świecie, [w:] Świat wobec wspótczesnych wyzwań i zagrożeń, red. J. Symonides, Warszawa 2010, s. 320.

16 Por. M. Kopytowska, Ł. Grabowski, European Security under Threat: Mediating the Crisis and Constructing the Other, [w:] National Identity and Europe in Times of Crisis Subtitle: Doing and Undoing Europe, red. C. Karner, M. Kopytowska, Bingley 2017, oraz M. Kopytowska, Ł. Grabowski, J. Woźniak, Mobilizing against the Other: Cyberhate, Refugee Crisis and Proximization, [w:] Contemporary Discourses of Hate and Radicalism across Space and Genres, red. M. Kopytowska, Amsterdam 2017 (w druku).

17 Ogólny stosunek do przyjmowania uchodźców/imigrantów ekonomicznych przez Polskę utrzymuje się na stałym poziomie. Odsetek Polaków, którzy są przeciwni napływowi imigrantów do naszego kraju, wynosił w 2018 r. 60\% (spadek o 3\% w porównaniu z r. 2017). 29\% respondentów uważało, że powinniśmy przyjmować uchodźców do czasu, kiedy będą mogli wrócić do kraju pochodzenia, zaś $5 \%$ było zdania, że powinniśmy pozwolić na osiedlanie się uchodźców w Polsce (CBOS 2018). Na negatywne nastawienie Polaków do uchodźców/imigrantów mają wpływ przekazy medialne, które wzmacniają obawy przed takimi osobami ze względów politycznych (por. Uchodźcy.info 2019). 
bezpieczeństwa catych grup spotecznych, przebudowie ulegaja więzi spoteczne i struktura spoteczna, a sytuacja bytowa ludzi pogarsza się. Wszelkie objawy „inności” definiowane sa wówczas jako „obcośc" zagrażająca "swoim"18.

Negatywne podejście do kształtowania się coraz większego pluralizmu kulturowego w Polsce jest w ostatnim czasie wyraźnie widoczne także w wypowiedziach internautów, które - jak pokazują badania - zawierają szereg strategii językowych służących budowaniu negatywnego wizerunku „Innego” i wzbudzaniu niechęci wobec uchodźców/ imigrantów ekonomicznych. Język, jakim posługują się niektórzy użytkownicy internetu, ukazuje ogromną skalę nietolerancji, a nawet nienawiści skierowanej do osób o innym niż polskie pochodzeniu narodowym/etnicznym.

\section{INTERNETOWA MOWA NIENAWIŚCI - PRZYCZYNY I KONSEKWENCJE}

„Mowa nienawiści” (ang. hatespeech) jest przestępstwem i podlega karze na mocy odpowiednich przepisów prawnych. Analizując przyczyny i konsekwencje mowy nienawiści, należy pamiętać, iż jest to skrajna forma „hejtu”, rozumianego jako używanie wyrazów powszechnie uważanych za obraźliwe, które mają zdyskredytować osobę publicznie znaną lub - w przypadku młodzieży - nielubianego rówieśnika ${ }^{19}$. Emilia Szymczak wskazuje na trzy grupy ludzi odpowiedzialnych za eskalację hejtu ${ }^{20}$. Pierwsza to osoby, które uważają, że wyższość grupy dominującej nad grupą słabszą jest społecznie uzasadniona, a tym samym słabsi przeciwnicy powinni być sukcesywnie eliminowani. Druga grupa to społeczność internautów, którzy, korzystając z zasłony anonimowości, mogą wypowiadać się z perspektywy innej roli społecznej niż ta, którą pełnią na co dzień (mogą rekonstruować swoją tożsamość zależnie od kontekstu, w którym chcą wyrazić swoje poglądy). Trzecia grupa (opłacanych) hejterów to osoby, których zadaniem jest umieszczanie na forach wpisów mających na celu pozyskanie klientów dla danego produktu, wyeliminowanie konkurencji lub zmniejszenie poparcia społecznego opozycji. Marta Juza wskazuje na jeszcze jeden typ internautów, dla których hejt (zwłaszcza ukierunkowany na celebrytów) jest formą rozrywki. Jako przykład podaje grupę założoną na Facebooku, która nosi nazwę „Hejtuję, bo lubię"21. Pojęcie hejtu odnosi się do szerokiego spektrum agresywnych wypowiedzi, których wspólną cechą charakterystyczną

18 I. Krzemiński, Rasizm, [w:] Encyklopedia socjologii, t. 3, Warszawa 2000, s. 282.

19 Sprawca hejtu może zostać ukarany tylko wtedy, gdy ofiara zgłosi odpowiednim organom ścigania wniosek o wszczęcie postępowania karnego (odnalezienie autora hejtu jest jednak w praktyce niezmiernie trudne ze względu na łatwość ukrycia się w cyberprzestrzeni).

20 E. Szymczak, Hejting jako przyktad wspótczesnego zagrożenia w przestrzeni społecznej, „Studia Edukacyjne" 2015, nr 37, [online] http://www.repozytorium.amu.edu.pl/bitstream/10593/14438/1/ SE_37_2015_Szymczak.pdf, 30 VIII 2017.

21 M. Juza, Hejterstwo w komunikacji internetowej: charakterystyka zjawiska, przyczyny i sposoby przeciwdziatania, „Profilaktyka Społeczna i Resocjalizacja” 2015, nr 25, [online], http:// www.hejterstwo_w_komunikacji_internetowej.pdf, 30 VIII 2017. 
jest to, że skierowane są do pojedynczych osób. Dlatego hejt, określany też jako „język wrogości”,22 należy odróżnić od węziej rozumianej „mowy nienawiści”, która zawsze kierowana jest do zbiorowości, a jeśli nawet wymierzona jest w jednostkę, to postrzeganą jako przedstawiciel grupy mniejszościowej o określonych cechach definiujących tę grupę. Jak mówią Kowalski i Tulli: mowa nienawiści adresowana jest do zbiorowości, a nie jednostek. Nawet jeśli uderza na pozór w konkretnego cztowieka, czyni to, redukują go do roli typowego przedstawiciela grupy [...], odziera go zindywidualności. [...] Mowa nienawiści skierowana jest przeciwko zbiorowościom szczególnego rodzaju, takim, których się w zasadzie nie wybiera ${ }^{23}$.

Ze względu na fakt, że w Unii Europejskiej nie obowiązują jednolite przepisy dotyczące mowy nienawiści, poszczególne państwa członkowskie podchodzą różnie do tego procederu ${ }^{24}$. W polskich zapisach prawnych termin „mowa nienawiści”, który jest określeniem bardzo ogólnym, nie występuje. Różne formy tego zjawiska opisywane są w sumie w kilkunastu artykułach kodeksu karnego, cywilnego i kodeksu pracy, przede wszystkim w artykule $257 \mathrm{KK}^{25}$, zgodnie z którym: Kto publicznie znieważa grupęludności albo poszczególnq osobę z powodu jej przynależności narodowej, etnicznej, rasowej, wyznaniowej albo z powodu jej bezwyznaniowości lub z takich powodów narusza nietykalność cielesna innej osoby, podlega karze pozbawienia wolności do lat trzech ${ }^{26}$. Zatem publiczne obrażanie kogokolwiek z powodu jego przynależności do danej rasy, grupy etnicznej, narodu czy grupy wyznaniowej (lub deklaracji, że jest ateistą) jest prawnie zabronione ${ }^{27}$. Bardziej szczegółową definicję „mowy nienawiści” opracowała Rada Europy. Zgodnie z nią: mowa nienawiści obejmuje wszelkie formy wypowiedzi, które szerza, propaguja czy usprawiedliwiaja nienawiść rasowa, ksenofobię, antysemityzm oraz inne formy nienawiści bazujące na nietolerancji, m.in.: nietolerancję wyrażająca się w agresywnym nacjonalizmie i etnocentryzmie, dyskryminację i wrogość wobec mniejszości, imigrantów i ludzi o imigranckim pochodzeniu ${ }^{28}$. Podatny grunt dla mowy nienawiści stanowią

22 M. Czyżewski, „Jezzyk wrogości” oraz spór o III i IV RP w perspektywie analizy dyskursu publicznego. Wybrane rezultaty projektu badawczego oraz uwagi metodologiczne, [w:] Jezyk IV Rzeczpospolitej, red. M. Czerwiński, P. Nowak, R. Przybylska, Lublin 2010.

23 S. Kowalski, M. Tulli, Zamiast procesu. Raport o mowie nienawiści, Warszawa 2003, s. 21-22.

24 Decyzja ramowa Rady UE 2008/913/JHA z dnia 28 listopada 2008 r., która dotyczy walki z pewnymi formami wyrażania rasizmu i ksenofobii za pomocą przepisów prawa karnego, zobowiązuje kraje członkowskie UE do karania celowego działania o następującym charakterze: 1) publiczne zachęcanie do przemocy lub nienawiści skierowanej przeciwko pojedynczej osobie lub grupie osób, które definiowane są poprzez swoją rasę, kolor skóry, religię, rodowód lub pochodzenie narodowe/etniczne; 2) promowanie tego typu działań za pomocą rozpowszechniania lub dystrybucji tekstów, zdjęć i innych materiałów.

25 Patrz np. artykuty: $256 \mathrm{KK}, 119 \mathrm{KK}, 194 \mathrm{KK}$.

26 Kodeks Karny - Ustawa z dnia 6 czerwca 1997 r. (Dz.U. nr 88, poz. 553 z późniejszymi poprawkami).

27 Nadal nie ma odpowiednich przepisów, które by dostatecznie chroniły przed mową nienawiści osoby o innej niż heteronormatywna orientacji seksualnej, dlatego takie przypadki można karać jedynie na podstawie przepisów dotyczących zniesławienia (por. artykuł $212 \mathrm{KK}$ ).

28 Rekomendacja nr R 97 (20) Komitetu Ministrów Rady Europy w kwestii „wypowiedzi szerzących nienawiść". 
ksenofobia, brak tradycji pokojowego współbytowania z grupami mniejszościowymi i brak akceptacji dla różnorodności kulturowej. W takiej sytuacji każdy „Inny” może stać się celem ataku słownego dla osób, które kierują się frustracją i lękiem przed innością, a swoją wiedzę o osobach odmiennych kulturowo opierają na stereotypach.

Mowa nienawiści jest agresją ukierunkowaną na wybraną grupę ludzi i nie wnosi do wypowiedzi żadnej merytorycznej treści. Zjawisko to ma jednak daleko idące konsekwencje społeczne, gdyż może stanowić podglebie dla postaw antagonistycznych wobec przedstawicieli obrażanych grup, a w dalszej perspektywie - agresywnego zachowania wobec tych osób (w tym: przestępstw motywowanych nienawiścią). Psycholodzy zwracają uwagę na fakt, iż osoby, które mają częsty kontakt z mową nienawiści, ulegają zjawisku określanemu jako desensytyzacja (odwrażliwienie), tzn. nie rozumieją, że tego typu wypowiedzi są działaniem nagannym i krzywdzącym innych. Ludzie niewrażliwi na agresję werbalną nie odczuwają też sprzeciwu wobec agresji fizycznej, są więc skłonni stosować i akceptować przemoc w kontaktach międzyludzkich. Długotrwała ekspozycja na mowę nienawiści wywołuje zatem efekt podobny do skutków, jakie powodują brutalne gry komputerowe ${ }^{29}$. Ponadto, wyniki badań mówią nie tylko o negatywnych skutkach dla autorów mowy nienawiści i osób, które często obcują z tego typu treściami, ale także ujawniają destrukcyjny wpływ mowy nienawiści na psychikę osób, do których jest ona kierowana. Brian Mullen i Joshua M. Smyth, którzy analizowali sytuację różnych grup mniejszościowych narażonych na obraźliwe określenia, zauważyli, że przedstawiciele tych grup byli nie tylko dyskryminowani społecznie, ale też doświadczali problemów psychicznych, włącznie z wykazywaniem podwyższonego ryzyka samobójstwa (społeczności narażone na najbardziej dotkliwe formy mowy nienawiści charakteryzowały się najwyższym wskaźnikiem samobójstw) ${ }^{30}$. Podobne badania były też prowadzone na gruncie polskim, m.in. przez Fundację Dzieci Niczyje ${ }^{31}$. Ich wyniki ujawnily, że - po pierwsze - 40\% osób w przedziale wiekowym $14-17$ lat i $45 \%$ w przedziale 16-17 lat natknęło się już w internecie na przejawy mowy nienawiści (obraźliwe komentarze lub dyskusje na forach), a po drugie - osoby, które miały kontakt z agresywnymi treściami, wykazywały większą skłonność do stanów depresyjnych i lękowych.

Zjawisko mowy nienawiści przybiera na sile $\mathrm{w}$ wielu krajach europejskich, co z kolei jest skutkiem wzmacniania się negatywnych nastrojów społecznych wobec uchodźców/imigrantów ekonomicznych (podsycanych przez głosy skrajnie prawicowe) ${ }^{32}$, jak

29 Por. M. Gajewski, Niebezpieczne gry komputerowe, „Wychowawca” 2002, nr 1.

30 B. Mullen, J.M. Smyth, Immigrant Suicide Rates as a Function of Ethnophaulisms: Hate Speech Predicts Death, „Psychosomatic Medicine” 2004, vol. 66, nr 3.

31 J. Włodarczyk, Zagrożenia związane z korzystaniem z Internetu przez mtodziez. Wyniki badania EU NET ADB, „Dziecko Krzywdzone. Teoria, Badania, Praktyka” 2013, nr 12(1); J. Włodarczyk, Mowa nienawiśsi w Internecie w doświadczeniu polskiej mtodzieży, „Dziecko Krzywdzone. Teoria, Badania, Praktyka” 2014, nr 13(2).

32 W ostatnich latach pojawiło się wiele głosów zdecydowanie krytycznych wobec idei wielokulturowości, które wywodzą się z tzw. ruchu Alt-Right (Alternative Right - Alternatywna Prawica). Jest to niejednorodny ruch polityczny obejmujący skrajnie prawicowe ideologie, które sprzeciwiają się wielokulturowości, migracji, a także walce o większe prawa mniejszości etnicznych, kobiet, homoseksualistów i innych grup (por. A. Nagle, Kill All Normies, Ropley 2017). 
również radykalizacji języka debaty publicznej, którą cechuje emocjonalność, agresywność, silne eksponowanie opozycji my-oni, inni, obcy [czy] szerzenie dychotomicznej wizji $s^{w i a t a}{ }^{33}$. Badania mowy nienawiści prowadzone w ostatnim czasie przez wiele ośrodków badawczych obejmują nie tylko monitorowanie mediów i identyfikowanie przykładów mowy nienawiści, ale także analizowanie powszechnej percepcji mowy nienawiści. Przykładem badania ostatniego typu była ankieta internetowa, której wyniki przedstawiamy poniżej.

\section{PERCEPCJA MOWY NIENAWIŚCI - BADANIE ANKIETOWE}

Prezentowane tu badanie ankietowe, przeprowadzone w ramach projektu C.O.N.T.A.C.T., miało na celu analizę percepcji mowy nienawiści przez obywateli Polski z przedziału wiekowego 18-35 lat. Wyniki badania zbierane były w listopadzie i grudniu 2016 r. (do skonstruowania i udostępnienia ankiety online posłużyły formularze Google), a całkowita liczba ankiet wyniosła 457 (106 mężczyzn, 350 kobiet, jedna osoba nie określiła swojej płci). Większość respondentów lokowała się w przedziale wiekowym 18-23 lata (57,3\%), nieco mniej w przedziale 24-29 lat (25,3\%), a najmniej w przedziale 30-35 lat (17,4\%). Odnosząc się do pytania o narodowość, 96,1\% określiło ją jako „polską”, 3,2\% zadeklarowało „mieszaną”, a 0,7\% - „inną”. Ankieta składała się z siedmiu pytań, przy czym niektóre z nich były często uzupełnione pytaniami dodatkowymi ${ }^{34}$. Na podstawie typu kanałów informacyjnych, za pomocą których dystrybuowany był link kwestionariusza, jak również danych zawartych w ankietach (pytanie o wykształcenie, na które 54,9\% respondentów odpowiedziało „wyższe”, 44,9\% „średnie”, 0,2\% podstawowe), można uznać, że respondenci byli w przeważającej mierze obecnymi lub byłymi studentami.

W pierwszej części kwestionariusza respondenci zostali poproszeni o ocenę trzech przykładowych komentarzy, które zostały umieszczone pod filmikami z portalu YouTube dotyczącymi uchodźców (we wszystkich komentarzach zachowano pisownię oryginalną) $)^{35}$. Wyniki przedstawione poniżej w formie tabelarycznej pokazują odsetek respondentów, którzy - korzystając z tzw. skali Likerta - uznali daną wypowiedź za: a) zdecydowanie dopuszczalną, b) raczej dopuszczalną, c) raczej niedopuszczalną i d) zdecydowanie niedopuszczalną.

33 I. Kamińska-Szmaj, Magiczna mowa wtadzy. O języku polityki, czyli od oratorów, propagandzistów do marketingowców, „Niezbędnik Inteligenta. Wydanie specjalne »Polityki«” 2012, nr 11, s. 84.

34 Wzór ankiety został opracowany przez Fabienne Baider (Uniwersytet Cypryjski), Sharon Millar (Uniwersytet Południowej Danii) i Cesara Arroyo (Asociación Socio Educativa Llere), którzy są członkami projektowego zespołu badawczego. Polska wersja ankiety została opracowana przez dr. hab. Łukasza Grabowskiego z Uniwersytetu Opolskiego (więcej informacji na temat ankiety znajduje się na stronie projektu C.O.N.T.A.C.T.: www.reportinghate.eu).

35 Ankieta obejmowała sześć komentarzy, ale tylko trzy z nich dotyczyły uchodźców (pozostałe trzy grup LGBT). Komentarze dobrane były tak, by jeden z nich wyrażał stosunek zdecydowanie negatywny, drugi raczej negatywny, trzeci zaś neutralny bądź pozytywny wobec danej grupy. 


\section{Komentarz 1:}

W ramach „Polskiej goscinnosci”, kazdemu ciapatemu i asfaltowemu smieciowi kulka $9 \mathrm{~mm}$ miedzy oczy... Moze wtedy to „ludzkie” GOWNO zacznie trybic, ze nikt tu nie chce pierdolonych negatywow i pustynnych czarnuchow w Europie/Polsce.

Tabela 1. Stopień akceptacji komentarza 1

\begin{tabular}{|c|c|c|c|}
\hline $\begin{array}{c}\text { Zdecydowanie } \\
\text { dopuszczalna }\end{array}$ & $\begin{array}{c}\text { Raczej } \\
\text { dopuszczalna }\end{array}$ & $\begin{array}{c}\text { Raczej } \\
\text { niedopuszczalna }\end{array}$ & $\begin{array}{c}\text { Zdecydowanie } \\
\text { niedopuszczalna }\end{array}$ \\
\hline $1,8 \%$ & $1,3 \%$ & $7,6 \%$ & $89,3 \%$ \\
\hline
\end{tabular}

Źródło: opracowanie własne

\section{Komentarz 2:}

Dla tych „ludzi” [uchodźców] nie ma miejsca w naszym społeczeństwie. Czują się bezkarni, mają za nic wartości innych narodów.

Tabela 2. Stopień akceptacji komentarza 2

\begin{tabular}{|c|c|c|c|}
\hline $\begin{array}{c}\text { Zdecydowanie } \\
\text { dopuszczalna }\end{array}$ & Raczej dopuszczalna & $\begin{array}{c}\text { Raczej } \\
\text { niedopuszczalna }\end{array}$ & $\begin{array}{c}\text { Zdecydowanie } \\
\text { niedopuszczalna }\end{array}$ \\
\hline $11,6 \%$ & $24,9 \%$ & $31,6 \%$ & $31,9 \%$ \\
\hline
\end{tabular}

Źródło: opracowanie własne

\section{Komentarz 3:}

Uchodźcom musimy pomóc - to nasz zasrany obowiązek. Kto by to nie był, drugiemu zawsze winni jesteśmy serdeczność i szacunek. I to nie ważne czy chrześcijanin, muzułmanin, buddysta albo nie ważne czy to człowiek, krowa czy kura (chyba, że jest naszym wrogiem).

Tabela 3. Stopień akceptacji komentarza 3

\begin{tabular}{|c|c|c|c|}
\hline $\begin{array}{c}\text { Zdecydowanie } \\
\text { dopuszczalna }\end{array}$ & Raczej dopuszczalna & $\begin{array}{c}\text { Raczej } \\
\text { niedopuszczalna }\end{array}$ & $\begin{array}{c}\text { Zdecydowanie } \\
\text { niedopuszczalna }\end{array}$ \\
\hline $14,7 \%$ & $50,7 \%$ & $27,6 \%$ & $7 \%$ \\
\hline
\end{tabular}

Źródło: opracowanie własne

Jak wynika z przytoczonych wyżej wyników, respondenci w przeważającej mierze nie akceptują obraźliwego języka, ale akceptują argumenty podkreślające odmienność uchodźców w zakresie standardów moralnych i systemów wartości.

Pytania o stopień dopuszczalności wyżej przytoczonych wypowiedzi uzupełniane były pytaniem o to, czy zostałyby one ocenione inaczej, gdyby nie znajdowały się na ogólnodostępnych forach, tylko w prywatnej przestrzeni internetowej (e-maile, chaty, prywatne strony w serwisie Facebook itp.), do której dostęp ma tylko wąskie grono użytkowników internetu. Respondenci odpowiedzieli na to pytanie w następujący sposób: 
Tabela 4. Stopień akceptacji komentarzy 1, 2 i 3, gdyby znajdowały się $\mathrm{w}$ prywatnej przestrzeni internetowej

\begin{tabular}{|c|c|c|}
\hline Tak & Nie & Nie wiem \\
\hline $29,5 \%$ & $57,3 \%$ & $13,2 \%$ \\
\hline
\end{tabular}

Źródło: opracowanie własne

W dalszej części tego pytania 61,4\% respondentów, którzy odpowiedzieli „Tak”, stwierdziło, iż w kontekście prywatnym komentarze byłyby bardziej dopuszczalne, co może wskazywać na fakt, że w takim kontekście internauci są mniej wyczuleni na normy społeczne dotyczące języka, jakim się posługują, jak również na sposób, w jaki opisują „Innych”.

Na pytanie, czy kiedykolwiek byli celem ataku słownego ze względu na kolor skóry, narodowość, pochodzenie etniczne, religię czy płeć, respondenci odpowiedzieli, że najczęstszym powodem szykan była płeć $\mathrm{i}$ wyznanie:

Tabela 5. Powody ataków słownych, jakich doświadczyli respondenci

\begin{tabular}{|c|c|c|c|c|}
\hline & Tak - często & Tak - rzadko & Nie & Nie wiem \\
\hline Narodowość & $2 \%$ & $14,4 \%$ & $81,6 \%$ & $2 \%$ \\
\hline Kolor skóry & $0,8 \%$ & $3,1 \%$ & $95,4 \%$ & $0,7 \%$ \\
\hline Pochodzenie narodowe/etniczne & $0,9 \%$ & $6,3 \%$ & $91,9 \%$ & $0,9 \%$ \\
\hline Religia & $5 \%$ & $21 \%$ & $73,1 \%$ & $0,9 \%$ \\
\hline Płeć & $6,6 \%$ & $30,4 \%$ & $60,6 \%$ & $2,4 \%$ \\
\hline Orientacja seksualna & $3,1 \%$ & $5,8 \%$ & $90,4 \%$ & $0,7 \%$ \\
\hline
\end{tabular}

Źródło: opracowanie własne

W pytaniu uzupełniającym respondenci wskazali na miejsca, w których padli ofiarą groźby lub zniewagi:

Tabela 6. Miejsca, w których respondenci doświadczyli ataków słownych

\begin{tabular}{|c|c|c|c|c|c|}
\hline W szkole & W internecie & Na ulicy & $\begin{array}{c}\text { W transporcie } \\
\text { publicznym }\end{array}$ & W pracy & $\begin{array}{c}\text { W kontekście } \\
\text { sportu }\end{array}$ \\
\hline $59,3 \%$ & $46,3 \%$ & $41,1 \%$ & $23,3 \%$ & $23,3 \%$ & $14,1 \%$ \\
\hline
\end{tabular}

Źródło: opracowanie własne

Kolejne pytanie brzmiało: „Czy kiedykolwiek byłeś świadkiem sytuacji, w której ktoś był obiektem obelg lub gróźb z uwagi na kolor skóry, narodowość, pochodzenie etniczne, religię czy płeć?". Odpowiedzi były następujące: 
Tabela 7. Odpowiedzi respondentów na pytanie, czy byli świadkami ataku słownego

\begin{tabular}{|c|c|c|c|c|}
\hline & Tak - często & Tak - rzadko & Nie & Nie wiem \\
\hline Narodowość & $23,4 \%$ & $38,9 \%$ & $37 \%$ & $0,7 \%$ \\
\hline Kolor skóry & $24,7 \%$ & $40,9 \%$ & $33,7 \%$ & $0,7 \%$ \\
\hline Pochodzenie narodowe/etniczne & $21 \%$ & $32,2 \%$ & $44,2 \%$ & $2,6 \%$ \\
\hline Religia & $27,2 \%$ & $38,7 \%$ & $32,8 \%$ & $1,3 \%$ \\
\hline Płeć & $17,1 \%$ & $34,4 \%$ & $47 \%$ & $1,5 \%$ \\
\hline Orientacja seksualna & $34,6 \%$ & $37 \%$ & $27,1 \%$ & $1,3 \%$ \\
\hline
\end{tabular}

Źródło: opracowanie własne

W pytaniu uzupełniającym respondenci wskazali na miejsca, w których byli świadkami kierowanej do kogoś groźby lub zniewagi.

Tabela 8. Miejsca, w których respondenci byli świadkami ataku słownego. Suma podanych wartości przewyższa 100\%, gdyż respondenci mogli wskazać więcej niż jedno miejsce

\begin{tabular}{|c|c|c|c|c|c|}
\hline W szkole & W internecie & Na ulicy & $\begin{array}{c}\text { W transporcie } \\
\text { publicznym }\end{array}$ & W pracy & $\begin{array}{c}\text { W kontekście } \\
\text { sportu }\end{array}$ \\
\hline $57,9 \%$ & $83,4 \%$ & $71,9 \%$ & $55,6 \%$ & $25,2 \%$ & $24,7 \%$ \\
\hline
\end{tabular}

Źródło: opracowanie własne

Widać tu wyraźnie, że najczęściej u podłoża ataków słownych leżały: orientacja seksualna, religia i kolor skóry, zaś miejscem, w którym najczęściej do nich dochodziło, był internet. W pytaniu uzupełniającym respondenci podawali też inne powody, dla których oni sami lub ktoś inny byli/był obiektem obelg lub gróźb. Były to: wygląd, poglądy polityczne, figura, waga, odmienność wobec grupy wiekowej, sposób ubierania się, pochodzenie rodzinne, długość włosów, osiągnięcia naukowe bez przysłowiowego zakuwania, światopogląd, obrona innych przed objawami nienawiści, propagowanie wielokulturowości (wystarczył wyraz multi-kulti w nazwie profilu na Facebooku oraz zdjęcie w burce), subkultura, miejsce zamieszkania, niepełnosprawność, wykształcenie, wczesna ciąża, poglądy socjaldemokratyczne, lewactwo, pochodzenie z małej miejscowości, przynależność do subkultury jako nastolatka, brak markowych i modnych ubrań (modny telefon), nieco biedniejsi rodzice, upodobania (np. gust muzyczny), bieda, bycie grubą, deklarowanie feminizmu, sprawność. Należy tu zaznaczyć, że ze względu na ogólny charakter powyższych pytań, odpowiedzi dostarczają informacji nie tylko o groźbach/zniewagach noszących znamiona mowy nienawiści, ale także wypowiedziach, które sytuują się w szerszym obszarze tzw. agresji językowej.

Kolejna część ankiety dotyczyła kwestii zgłaszania incydentów noszących znamiona mowy nienawiści organom ścigania. Na pytanie, czy zgłosiliby na policję fakt, że byli ofiarą takiego ataku słownego, respondenci odpowiedzieli następująco: 
Tabela 9. Odpowiedzi respondentów na pytanie, czy zgłosiliby na policję fakt, że byli ofiarą mowy nienawiści

\begin{tabular}{|c|c|c|}
\hline Tak & Nie & Nie wiem \\
\hline $24,8 \%$ & $26,7 \%$ & $48,5 \%$ \\
\hline
\end{tabular}

Źródło: opracowanie własne

Z kolei pytani o to, czy zgłosiliby fakt, że ktoś inny był obiektem obelg lub gróźb z uwagi na kolor skóry, narodowość, pochodzenie etniczne, religię czy płeć, odpowiedzieli:

Tabela 10. Odpowiedzi respondentów na pytanie, czy zgłosiliby na policję fakt, że ktoś inny był ofiarą mowy nienawiści

\begin{tabular}{|c|c|c|}
\hline Tak & Nie & Nie wiem \\
\hline $29,3 \%$ & $19,3 \%$ & $51,4 \%$ \\
\hline
\end{tabular}

Źródło: opracowanie własne

W pytaniu uzupełniającym respondenci, którzy odpowiedzieli „Nie” lub „Nie wiem", wybierali następujące powody, dla których niekoniecznie poinformowaliby policję o tego typu sytuacji:

Tabela 11. Powody, dla których respondenci nie zdecydowaliby się zgłosić na policję incydentu noszącego znamiona mowy nienawiści

\begin{tabular}{|c|c|}
\hline Nie sądzę, aby policja lub organy ścigania cokolwiek z tym zrobiły & $67,9 \%$ \\
\hline Nie wiem, jak i gdzie zgłasza się podobne incydenty & $33,9 \%$ \\
\hline To zbyt duży kłopot & $31,2 \%$ \\
\hline Bałbym się konsekwencji zgłoszenia tego typu czynów & $23,7 \%$ \\
\hline Czułbym się zawstydzony, zakłopotany lub niekomfortowo & $22,6 \%$ \\
\hline Myślę, że to nie jest moja sprawa & $21,3 \%$ \\
\hline Nie sądzę, że jest to na tyle poważne, aby to zgłaszać & $14,1 \%$ \\
\hline Incydent jest czymś codziennym, więc nie ma sensu go gdziekolwiek zgłaszać & $9,6 \%$ \\
\hline
\end{tabular}

Źródło: opracowanie własne

Jak widać, wielu respondentów wyraziło opinię, iż organy ścigania są nieefektywne, a procedury zgłaszania takich incydentów - zbyt skomplikowane. Ujawnia to niepokojącą społeczną prawidłowość, że obywatele nie mają zaufania do policji i prokuratury w tym zakresie i nie wierzą w skuteczność podejmowanych przez nie działań. Daje się też zauważyć brak znajomości procedur zgłaszania tego typu przestępstw. Wreszcie, znacząca liczba respondentów nie postrzega agresji słownej jako kwestii zasługującej na uwagę organów ścigania. 
W kolejnej części ankiety respondenci mieli określić, na ile zgadzają się (lub nie zgadzają) z czterema różnymi definicjami mowy nienawiści sformułowanymi na potrzeby badania. Możliwe warianty odpowiedzi - według siedmiostopniowej skali Likerta obejmowały: „Zdecydowanie się zgadzam”, „Zgadzam się”, „,Raczej się zgadzam”, „Trudno powiedzieć”, „Raczej się nie zgadzam”, „Nie zgadzam się”, „Zdecydowanie się nie zgadzam”. Pytanie wprowadzające do tej części ankiety brzmiało: „Czy kiedykolwiek słyszałeś o pojęciu »mowa nienawiści«?” i respondenci odpowiedzieli na nie w następujący sposób:

Tabela 12. Odpowiedzi respondentów na pytanie: „Czy kiedykolwiek słyszałeś o pojęciu »mowa nienawiści «?"

\begin{tabular}{|c|c|c|}
\hline Tak & Nie & Nie przypominam sobie \\
\hline $84,5 \%$ & $9,2 \%$ & $6,3 \%$ \\
\hline
\end{tabular}

Źródło: opracowanie własne

\section{Definicja 1:}

„Mowa nienawiści oznacza wypowiadanie negatywnych, opartych na uprzedzeniach komentarzy na temat ludzi z powodu ich rasy lub narodowości, pochodzenia etnicznego, religii, płci lub orientacji seksualnej”.

Tabela 13. Opinie respondentów na temat definicji 1

\begin{tabular}{|c|c|}
\hline Zdecydowanie się zgadzam & $33,8 \%$ \\
\hline Zgadzam się & $36,8 \%$ \\
\hline Raczej się zgadzam & $18,2 \%$ \\
\hline Trudno powiedzieć & $4,6 \%$ \\
\hline Raczej się nie zgadzam & $2 \%$ \\
\hline Nie zgadzam się & $2,4 \%$ \\
\hline Zdecydowanie się nie zgadzam & $2,2 \%$ \\
\hline
\end{tabular}

Źródło: opracowanie własne

\section{Definicja 2:}

„Mowa nienawiści oznacza obrażanie kogoś ze względu na rasę, narodowość, pochodzenie etniczne, religię, płeć lub orientację seksualną".

Tabela 14. Opinie respondentów na temat definicji 2

\begin{tabular}{|c|c|}
\hline Zdecydowanie się zgadzam & $34,6 \%$ \\
\hline Zgadzam się & $43,7 \%$ \\
\hline Raczej się zgadzam & $14,2 \%$ \\
\hline Trudno powiedzieć & $3,5 \%$ \\
\hline
\end{tabular}




\begin{tabular}{|c|c|}
\hline Raczej się nie zgadzam & $1,1 \%$ \\
\hline Nie zgadzam się & $1,1 \%$ \\
\hline Zdecydowanie się nie zgadzam & $1,8 \%$ \\
\hline
\end{tabular}

Źródło: opracowanie własne

\section{Definicja 3:}

„Mowa nienawiści oznacza grożenie komuś ze względu na rasę, narodowość, pochodzenie etniczne, religię, płeć lub orientację seksualną”.

Tabela 15. Opinie respondentów na temat definicji 3

\begin{tabular}{|c|c|}
\hline Zdecydowanie się zgadzam & $40,5 \%$ \\
\hline Zgadzam się & $35,4 \%$ \\
\hline Raczej się zgadzam & $13,3 \%$ \\
\hline Trudno powiedzieć & $6,3 \%$ \\
\hline Raczej się nie zgadzam & $2 \%$ \\
\hline Nie zgadzam się & $1 \%$ \\
\hline Zdecydowanie się nie zgadzam & $1,5 \%$ \\
\hline
\end{tabular}

Źródło: opracowanie własne

\section{Definicja 4:}

„Mowa nienawiści oznacza nakłanianie innych do przemocy lub okazywania nienawiści wobec ludzi ze względu na rasę, narodowość, pochodzenie etniczne, religię, płeć lub orientację seksualną".

Tabela 16. Opinie respondentów na temat definicji 4

\begin{tabular}{|c|c|}
\hline Zdecydowanie się zgadzam & $39,6 \%$ \\
\hline Zgadzam się & $28,4 \%$ \\
\hline Raczej się zgadzam & $16,4 \%$ \\
\hline Trudno powiedzieć & $9,4 \%$ \\
\hline Raczej się nie zgadzam & $3,3 \%$ \\
\hline Nie zgadzam się & $1,5 \%$ \\
\hline Zdecydowanie się nie zgadzam & $1,4 \%$ \\
\hline
\end{tabular}

Źródło: opracowanie własne

Po każdej z definicji pojawiło się pytanie: „Czy powinny istnieć regulacje prawne w odniesieniu do tego rodzaju mowy nienawiści?”. Respondenci udzielili na to pytanie następujących odpowiedzi: 
Tabela 17. Odpowiedzi respondentów na pytanie: „Czy powinny istnieć regulacje prawne w odniesieniu do tego rodzaju mowy nienawiści?”

\begin{tabular}{|c|c|c|c|c|}
\hline & Definicja 1 & Definicja 2 & Definicja 3 & Definicja 4 \\
\hline Tak & $71,3 \%$ & $77,4 \%$ & $89,1 \%$ & $85,7 \%$ \\
\hline Nie & $13,4 \%$ & $8,8 \%$ & $2,8 \%$ & $4,2 \%$ \\
\hline Nie wiem & $15,3 \%$ & $13,8 \%$ & $8,1 \%$ & $10,1 \%$ \\
\hline
\end{tabular}

Źródło: opracowanie własne

Warto tu zauważyć, iż większość respondentów zgadza się z rozumieniem mowy nienawiści jako wyrażaniem opartych na uprzedzeniach negatywnych komentarzy, obrażaniem, grożeniem czy zachęcaniem do przemocy wobec „Innych”. Ponadto, większość z nich uważa też, że powinny istnieć regulacje prawne w tym zakresie, jednak opinie różnią się co do tego, jaki typ mowy nienawiści powinien być karany, tzn. w miarę jak definicja rozszerza się od samych komentarzy, poprzez znieważanie w kierunku do gróźb i nakłaniania, coraz więcej osób stwierdza, że powinny istnieć odpowiednie przepisy, które penalizowałyby mowę nienawiści. Widać zatem, iż negatywne komentarze umieszczane w internecie są w mniejszym stopniu postrzegane jako działania wymagające regulacji prawnych niż groźby i przemoc fizyczna.

Powyższe wyniki pokazują także, że percepcja mowy nienawiści przez osoby, które wzięły udział w ankiecie, nie jest jednoznacznie negatywna. Pewien odsetek respondentów uważa za dopuszczalne komentowanie kwestii dotyczących uchodźców/imigrantów ekonomicznych za pomocą sformułowań nacechowanych agresją słowną. Jest to tym bardziej niepokojące, że - jak już wspomniano - osoby, które wzięły udział w badaniu, to w zdecydowanej większości studenci.

\section{WNIOSKI KOŃCOWE}

W dobie masowych migracji kraje europejskie będące obiektem aspiracji uchodźców i imigrantów zarobkowych muszą wypracować podejście do kwestii masowych migracji i współbytowania z osobami odmiennymi kulturowo, biorąc pod uwagę to - jak mówi Marian Golka - jak sprostać z jednej strony ideologii otwarcia (i hastom typu: "Einstein też byt emigrantem"), a także wtasnym problemom demograficznym (starzenie się spoteczeństw europejskich) oraz problemom gospodarczym (brak rak do pracy niewykwalifikowanej), a z drugiejpodotać ciężarom utrzymywania imigrantów i ktopotom wynikającym $z$ nieudanej, bo zazwyczaj nadmiernej i realizowanej w zbyt szybkim tempie wielokulturowości (co skądinad ciagle przypominaja i podkreślają partie prawicowe ${ }^{36}$. Z powyższymi dylematami będzie musiała zmierzyć się również Polska, a to oznacza, że Polacy będą doświadczać procesu stopniowego przekształcania się społeczeństwa polskiego w społeczeństwo pluralistyczne kulturowo. Aby było to doświadczenie pozytywne, potrzeb-

36 M. Golka, Cywilizacja wspótczesna i globalne problemy, Warszawa 2012, s. 277-278. 
ne są systemowe działania edukacyjne umożliwiające obywatelom nabycie kompetencji międzykulturowych, które ułatwią im skuteczną i opartą na wzajemnym szacunku komunikację z osobami odwołującymi się do innych wzorców kulturowych w zakresie zachowania, stylu rozmowy czy kultywowanych tradycji ${ }^{37}$.

Przedstawione powyżej wyniki badań pokazują, iż młodzi ludzie często nie zdają sobie sprawy z konsekwencji mowy nienawiści, a co za tym idzie - odpowiedzialności zarówno moralnej, jak i prawnej, jaką ponosi autor tego typu wypowiedzi. Niezbędne wydają się zatem także odpowiednie programy szkoleniowe dotyczące mowy nienawiści, które mogłyby zwiększyć świadomość społeczną na temat skali tego zjawiska, jego potencjalnych skutków (prawnych, społecznych i psychicznych), jak również sposobów reagowania na takie przypadki. Aby można było skutecznie walczyć z mową nienawiści, nie wystarczą jednak same działania edukacyjne, odpowiednie przepisy prawne czy skuteczna moderacja forów internetowych. Potrzebna jest atmosfera zrozumienia i akceptacji dla idei wielokulturowości jako modelu politycznego, w jakim funkcjonuje wiele współczesnych społeczeństw, oraz dyskurs doceniania dyfuzji kulturowej. Konieczne jest także wypracowanie takich norm społecznych, które pozwoliłyby na pokojową koegzystencję osób o różnym rodowodzie kulturowym. Negatywne nastawienie do idei pluralizmu kulturowego w Polsce (i w Europie) może być postrzegane zarówno jako przyczyna, jak i skutek upowszechniającego się w debacie publicznej radykalnego dyskursu ksenofobicznego i internetowej mowy nienawiści, dlatego interdyscyplinarne badania zagadnienia mowy nienawiści skierowanej do osób odmiennych kulturowo mogą znacząco przyczynić się do wypracowania skutecznych środków zaradczych wobec tego zjawiska. Ostatecznie, przyszłość idei wielokulturowości zależy od tego, czy obywatele zrozumieją, że korzyści płynące z takiej polityki są warte wysiłku, a alternatywą jest coraz większa polaryzacja i agresja między grupami mniejszościowymi a spoleczeństwem gospodarzy.

\section{BIBLIOGRAFIA}

Berry J.W., Acculturation: Living Successfully in Two Cultures, „International Journal of Intercultural Relations" 2005, vol. 29, https://doi.org/10.1016/j.ijintrel.2005.07.013.

CBOS - Centrum Badania Opinii Społecznej, Stosunek Polaków i Czechów do przyjmowania uchodźców. Komunikatzbadańnr 87/2018, [online] https://www.cbos.pl/SPISKOM.POL/ 2018/K_087_18.PDF.

Chromiec E., Mniejszości narodowe i etniczne w Polsce - pytania i problemy okresu transformacji, [w:] Spoteczeństwo wobec „Innego". Kategoria "Innego" w naukach spotecznych i życiu publicznym, red. L. Dziewięcka-Bokun, A. Śledzińska-Simon, Toruń 2010.

37 Jak pisze Iwona Sobieraj: Cecha kompetencji międzykulturowych jest [...] wiedza nie tylko uświadomiona, ale także nabyta intencjonalnie przez jednostkę dążaca do zrozumienia przedstawicieli innej kultury bądź interakcji międzykulturowych (I. Sobieraj, Kompetencje międzykulturowe jako kapitat wspótczesnego cztowieka. Przestrzeń Unii Europejskiej, [w:] Wielokulturowość: konflikt..., s. 205). Por. S.J. Magala, Kompetencje międzykulturowe, Warszawa 2011. 
Czyżewski M., „Język wrogości” oraz spór o III i IV RP w perspektywie analizy dyskursu publicznego. Wybrane rezultaty projektu badawczego oraz uwagi metodologiczne, [w:] Jezyk IV Rzeczpospolitej, red. M. Czerwiński, P. Nowak, R. Przybylska, Lublin 2010.

Gajewski M., Niebezpieczne gry komputerowe, „Wychowawca” 2002, nr 1.

Giddens A., Europa w epoce globalnej, przeł. M. Klimowicz, M. Habura, Warszawa 2009.

Giza A., Głowacka-Grajper M., Urbańska S., Mieszkańcy Polski, [w:] Wspótczesne spoteczeństwo polskie, red. A. Giza, M. Sikorska, Warszawa 2012.

Golka M., Cywilizacja wspótczesna i globalne problemy, Warszawa 2012.

Jawor A., Wojna kultur. Czy „flaga tęczowa” wypiera „biato-czerwona”?, Warszawa 2014.

Juza M., Hejterstwo w komunikacji internetowej: charakterystyka zjawiska, przyczyny i sposoby przeciwdziatania, „Profilaktyka Społeczna i Resocjalizacja” 2015, nr 25, s. 27-50, [online] www.hejterstwo_w_komunikacji_internetowej.pdf.

Kamińska-Szmaj I., Magiczna mowa wtadzy. O języku polityki, czyli od oratorów, propagandzistów do marketingowców, „Niezbędnik Inteligenta. Wydanie specjalne »Polityki«” 2012, nr 11.

Karwińska A., Poziom mezospoteczny, [w:] Odkrywanie socjologii. Podręcznik dla ekonomistów, red. A. Karwińska, Warszawa 2008.

Kopytowska M., Grabowski Ł., European Security under Threat: Mediating the Crisis and Constructing the Other, [w:] National Identity and Europe in Times of Crisis Subtitle: Doing and Undoing Europe, red. C. Karner, M. Kopytowska, Bingley 2017, https://doi.org/ 10.1108/978-1-78714-513-920171005.

Kopytowska M., Grabowski Ł., Woźniak J., Mobilizing against the Other: Cyberhate, Refugee Crisis and Proximization, [w:] Contemporary Discourses of Hate and Radicalism across Space and Genres, red. M. Kopytowska, Amsterdam 2017 (w druku), https://doi.org/10.1075/bct.93.

Kowalski S., Tulli M., Zamiast procesu. Raport o mowie nienawiści, Warszawa 2003.

Krzemiński I., Rasizm, [w:] Encyklopedia socjologii, t. 3, Warszawa 2000.

Kwiatkowska A., Chodkowska H., Identity in a Multicultural Environment: a Gender Perspective, [w:] Culture and Gender in Intimate Relation, red. A. Chybicka, S.F. Safdar, A. Kwiatkowska, Gdańsk 2010.

Magala S.J., Kompetencje międzykulturowe, Warszawa 2011.

Mikułowski Pomorski J., Komunikacja międzykulturowa jako dziedzina nauki. Z historii komunikacji międzykulturowej, [w:] Polifonia, dialog i zderzenie kultur. Antologia tekstów z komunikacji międzykulturowej, red. U. Kusio, Torun 2007.

Modood T., Multikulturalizm, przeł. I. Kołbon, Poznań 2014.

Mullen B., Smyth J.M., Immigrant Suicide Rates as a Function of Ethnophaulisms: Hate Speech Predicts Death, „Psychosomatic Medicine” 2004, vol. 66, nr 3.

Nagle A., Kill All Normies, Ropley 2017.

Nakonieczna J., Migracje międzynarodowe jako wyzwanie we wspótczesnym świecie, [w:] Świat wobec wspótczesnych wyzwań i zagrożeń, red. J. Symonides, Warszawa 2010.

Rada Europy, Decyzja Ramowa Rady UE 2008/913/JHA z dnia 28 listopada 2008 r., [online] www.eurlex.europa.eu/LexUriServ/LexUriServ.do?uri=OJ:L:2008:328:0055:0058:en:PDF.

Rada Europy, Rekomendacja nr R 97 (20) Komitetu Ministrów Rady Europy w kwestii „wypowiedzi szerzacych nienawiśc'”, [online] http://www.echr.coe.int/Documents/FS_Hate_s peech_POL.pdf. 
Sadowski A., Spoteczeństwo polskie - od zróżnicowanego kulturowo do wielokulturowego. Szanse i zagrożenia, [w:] Wielokulturowość: konflikt czy koegzystencja, red. A. Śliz, M.S. Szczepański, Warszawa 2011.

Sobieraj I., Kompetencje międzykulturowe jako kapitat wspótczesnego cztowieka. Przestrzeń Unii Europejskiej, [w:] Wielokulturowość: konflikt czy koegzystencja, red. A. Śliz, M.S. Szczepański, Warszawa 2011.

Stefaniak A., Witkowska M., Spoteczne kontakty Polaków, czyli czy znamy ludzi innych niż my sami i czy chcemy ich poznawać?, [w:] Uprzedzenia w Polsce, red. A. Stefaniak, M. Bilewicz, M. Winiewski, Warszawa 2015.

Szymczak E., Hejting jako przyktad wspótczesnego zagrożenia w przestrzeni spotecznej, „Studia Edukacyjne" 2015, nr 37, https://doi.org/10.14746/se.2015.37.7.

Tavris C., Wade C., Psychologia. Podejścia i koncepcje, przeł. J. Gilewicz, Poznań 1995.

Uchodźcy.info, Stosunek Polaków do uchodźców, 2019, [online] http://uchodzcy.info/infos/ stosunek-polakow-do-uchodzcow/.

Włodarczyk J., Zagrożenia związane z korzystaniem z Internetu przez mtodziez. Wyniki badania EUNET ADB, „Dziecko Krzywdzone. Teoria, Badania, Praktyka” 2013, nr 12(1), [online], http://fdds.pl/wp-content/uploads/2016/05/Wlodarczyk_J_2013_Zagrozenia_zwiazane_z_korzystaniem_z_internetu.pdf.

Włodarczyk J., Mowa nienawiści $w$ Internecie $w$ doświadczeniu polskiej mtodzieży, „Dziecko Krzywdzone. Teoria, Badania, Praktyka” 2014, nr 13(2), [online], http://www.mowanienawisci.info/post/mowa-nienawisci-w-internecie-w-doswiadczeniu-polskiej-mlodziezy/.

Ząbek M., Łodziński S., Uchodźcy w Polsce. Próba spojrzenia antropologicznego, Warszawa 2008.

Monika KOPYTOWSKA - dr, adiunkt w Zakładzie Pragmatyki UŁ, prowadzi badania i zajęcia dotyczące dyskursu mediów, komunikacji międzykulturowej oraz tożsamości w kontekście konfliktu. Profesor wizytujący w Lancaster University, University of Nairobi oraz egzaminator zewnętrzny tamże. Współpracuje z wieloma instytucjami edukacyjnymi i medialnymi w Afryce Wschodniej. Laureatka stypendium (2011) Departamentu Stanu USA dla edukatorów medialnych (SUSI). Współzałożycielka European Network for Intercultural Education Activities (ENIEDA). Redaktor naczelny "Lodz Papers in Pragmatics" (De Gruyter Mouton). Autorka wielu publikacji o zasięgu krajowym i zagranicznym.

Julita WOŹNIAK - dr, wykładowczyni akademicka (Uniwersytet Jana Kochanowskiego w Kielcach), trenerka międzykulturowa i trenerka edukacji globalnej. Do jej zainteresowań naukowych należą Krytyczna Analiza Dyskursu, dyskurs migracyjny i komunikacja międzykulturowa. Prowadziła warsztaty międzykulturowe dla licealistów, studentów, nauczycieli, seniorów, funkcjonariuszy policji i wolontariuszy pracujących z imigrantami. Członkini Stowarzyszenia SIETAR Polska. 